\title{
Dissecting Molecular Features of Gliomas: Genetic Loci and Validated Biomarkers
}

\author{
Antonietta Arcella 1,+(D), Fiona Limanaqi ${ }^{2,+}{ }^{(D)}$, Rosangela Ferese ${ }^{1}$, Francesca Biagioni ${ }^{1}$, \\ Maria Antonietta Oliva ${ }^{1}$, Marianna Storto ${ }^{1}$, Mirco Fanelli ${ }^{3}$, Stefano Gambardella ${ }^{1,3, *}$ \\ and Francesco Fornai 1,2,*(D) \\ 1 IRCCS Neuromed, Via Atinense 18, 86077 Pozzilli, Italy; arcella@neuromed.it (A.A.); \\ ferese.rosangela@gmail.com (R.F.); frbiagioni@libero.it (F.B.); olv78@homail.com (M.A.O.); \\ marianna.storto@neuromed.it (M.S.) \\ 2 Department of Translational Research and New Technologies on Medicine and Surgery, \\ University of Pisa, Via Roma 55, 56126 Pisa, Italy; f.limanaqi@studenti.unipi.it \\ 3 Department of Biomolecular Sciences, University of Urbino "Carlo Bò", 61029 Urbino, Italy; \\ mirco.fanelli@uniurb.it \\ * Correspondence: stefano.gambardella@uniurb.it (S.G.); francesco.fornai@med.unipi.it (F.F.) \\ + These authors contributed equally to this work.
}

Received: 23 November 2019; Accepted: 17 January 2020; Published: 20 January 2020

check for updates

\begin{abstract}
Recently, several studies focused on the genetics of gliomas. This allowed identifying several germline loci that contribute to individual risk for tumor development, as well as various somatic mutations that are key for disease classification. Unfortunately, none of the germline loci clearly confers increased risk per se. Contrariwise, somatic mutations identified within the glioma tissue define tumor genotype, thus representing valid diagnostic and prognostic markers. Thus, genetic features can be used in glioma classification and guided therapy. Such copious genomic variabilities are screened routinely in glioma diagnosis. In detail, Sanger sequencing or pyrosequencing, fluorescence in-situ hybridization, and microsatellite analyses were added to immunohistochemistry as diagnostic markers. Recently, Next Generation Sequencing was set-up as an all-in-one diagnostic tool aimed at detecting both DNA copy number variations and mutations in gliomas. This approach is widely used also to detect circulating tumor DNA within cerebrospinal fluid from patients affected by primary brain tumors. Such an approach is providing an alternative cost-effective strategy to genotype all gliomas, which allows avoiding surgical tissue collection and repeated tumor biopsies. This review summarizes available molecular features that represent solid tools for the genetic diagnosis of gliomas at present or in the next future.
\end{abstract}

Keywords: glioblastoma; Next Generation Sequencing; Biomarkers; liquid biopsy; molecular diagnostics

\section{Introduction}

The term "glioma" is commonly used to indicate solid tumors of the central nervous system (CNS) that may arise from and share histologic features with normal glial cells, namely astrocytes, oligodendrocytes, and ependymal cells. On this basis, gliomas are roughly classified as astrocytomas, oligodendrogliomas, and ependymomas, with each group including tumor subtypes that own different ranges of biological malignancy.

According to the traditional World Health Organization (WHO) classification, gliomas are roughly classified into four categories based on histological features (Figure 1). Grade I are solid and non-infiltrative tumors (pilocytic astrocytomas), while grades II-IV are diffuse infiltrating gliomas 
(DIGs) [1]. Grade II are commonly referred to as low-grade gliomas (LGGs), while the more aggressive tumors are referred to as high-grade gliomas (grade III and IV). Nonetheless, the WHO (IARC, Lyon) recommends avoiding the term "LGGs", since it brings together a heterogeneous group of tumors that may significantly differ in biological properties, prognoses, and treatments [2,3].

Grade III gliomas are invasive and aggressive, owning quick progression leading to high lethality. Grade IV tumors, also known as "Glioblastoma", are the most common and fatal adult brain tumors [4,5]. Glioblastoma is classified as either primary (de novo) or secondary in origin. Roughly $90 \%$ of glioblastomas develop rapidly de novo as primary glioblastomas, extremely aggressive tumors that affect mostly elederly patients [6]. Secondary glioblastomas (10\%) are derived from previously lower-grade (WHO grades II or III) gliomas, namely diffuse or anaplastic astrocytomas, and they manifest mostly in younger patients [6] Secondary glioblastomas present at the onset with similar clinical and histological features as their primary counterparts, though different genetic/epigenetic profiles and molecular pathways are involved [6].

In the last few years, the application of Next Generation Sequencing (NGS) has revolutionized our understanding of somatic changes occurring within the cancer genome. This led to better understand the inter- and intra-individual heterogeneity of tumors, and to develop classification schemes aimed at characterizing the molecular subtype, considering dysregulated pathways that can be common or specific to a subset of cancer types [7-15].

To date, subtypes of glioma show different molecular and genetic profiles. According to the most recent classification (WHO 2016), histopathological analysis should always be accompanied by genetic screening [16]. This represents a substantial change towards integrating the concept of morphological and genetic classifications when translating specific cell tumor pathology into clinical practice [16]. For instance, the diagnosis of oligodendroglioma requires that tumor harbors both an IDH1/2 mutation and a $1 \mathrm{p} / 19 \mathrm{q}$ codeletion. Moreover, astrocytomas are featured by the IDH1/2 mutation in the absence of $1 p / 19 q$ codeletion, while often harboring inactivating mutations in $\alpha$-thalassemia mental retardation $\mathrm{X}$-linked (ATRX) and tumor protein p53 (TP53) genes.

\begin{tabular}{c|ccc}
$\begin{array}{c}\text { Histology } \\
\text { WHO grade }\end{array}$ & Astrocytoma & Oligoastrocytoma & Oligodendroglioma \\
\hline $\begin{array}{c}\text { Grade I } \\
\text { (circumscript) }\end{array}$ & $\begin{array}{c}\text { Pilocytic } \\
\text { astrocytoma } \\
\text { Grade II } \\
\text { (low-grade) }\end{array}$ & $\begin{array}{c}\text { Diffuse } \\
\text { astrocytoma }\end{array}$ & Oligoastrocytoma Oligodendroglioma \\
$\begin{array}{c}\text { Grade III } \\
\text { (diffuse, high-grade) }\end{array}$ & $\begin{array}{c}\text { Anaplastic } \\
\text { astrocytoma }\end{array}$ & $\begin{array}{c}\text { Anaplastic } \\
\text { oligoastrocytoma }\end{array}$ & $\begin{array}{c}\text { Anaplastic } \\
\text { Grade IV }\end{array}$ \\
$\begin{array}{c}\text { Gigh-grade) } \\
\text { Glioblastoma }\end{array}$ & & & \\
\hline
\end{tabular}

Figure 1. Histological classification of gliomas according to the World Health Organization WHO (I-IV) grades.

Methylation profiling may be added to histological and standard genetic approaches to classify brain tumors, potentially refining future classifications [6]. In this scenario, tumor classification according to molecular subtypes represents a diagnostic, prognostic, and potentially therapeutic 
marker [3,7-10,17-21]. As a consequence, these molecular markers may overwrite the histological phenotype, which may significantly impact treatment options in each patient.

This review summarizes those main molecular and genetic features of gliomas that may represent solid tools for the genetic diagnosis at present and in the next future.

\section{Germline Features and Loci Influencing the Risk of Glioma}

The risk of gliomas is consistently elevated in first-degree relatives of patients with gliomas and other primary brain tumours. Therefore, a great effort has been made to understand the genetics of gliomas [22].

Most cases cannot be explained by causes related with endogenous or exogenous factors. In fact, the only generally accepted and well-defined risk factors are high doses of ionizing radiation and rare genetic syndromes. Unfortunately, they can only explain a small percentage of all gliomas.

Except for a few rare mendelian cancer predisposition syndromes (i.e., Li Fraumeni syndrome, Neurofibromatosis), the genetic basis of inherited susceptibility to gliomas is currently undefined given the unlikeness of a disease susceptibility model that is solely based on high-risk mutations. In fact, as demonstrated in other cancer diseases, much of the inherited risk is likely to be the result of the co-inheritance of common multiple low-risk variants. To this aim, genome-wide association studies (GWAS) and additional fine-mapping identified some common germline genetic variants associated with an increased risk of glioma [23-34]. To date, more than 25 genetic loci have been associated with an increased risk of developing glioma in adulthood [23-32]. Most genes located within these loci are affected by somatic mutations occurring in gliomas, namely cyclin-dependent kinase inhibitor $2 \mathrm{~A}$ and $\mathrm{B}(C D K N 2 A, C D K N 2 B)$, epidermal growth factor receptor (EGFR), telomerase reverse transcriptase (TERT), TP53, pleckstrin homology-like domain family B member 1 (PHLDB1), and regulator of telomere elongation helicase 1 (RTEL1) [26-28,35-38]. The first germline studies identified a locus on chromosome 9p21, encompassing the CDKN2A (MIM number 600160) and CDKN2B (MIM number 600431) tumor suppressor genes, which have an established role in glioma development. In keeping with this, homozygous deletion in CDKN2A is detectable in approximately $50 \%$ of tumors [7], and the loss of $C D K N 2 A$ expression is linked to poor prognosis. Furthermore, $C D K N 2 A$ germline mutations are responsible for the melanoma-astrocytoma syndrome (MIM number 155755), and genetic variants close to both $C D K N 2 A$ and $C D K N 2 B$ genes (on the chromosomal locus 9p21) are known to increase the risk for glioma, basal cell carcinoma, and melanoma [35].

Correlations between germline and somatic variants suggest that an association between germline genetic variation and environmentally-induced molecular alterations could diverge as a key to define a single molecular event in different gliomas. This is consistent with germline variants at 8q24.21, which are associated with IDH1-IDH2 mutated astrocytoma and oligodendroglial tumors [3].

Some germline genetic variants are associated with tumor grade. For example, high-grade gliomas are associated with risk variants in RTEL1, CDKN2B, and TERT [32,38], while low-grade gliomas with $I D H$ mutation-1p/19q codeletion are associated with risk variants in CCDC26 and PHLDB1 regions $[17,32,38]$. Although these germline loci confer increased individual risk, none of them does represent, per se, a reliable association to be used in clinical routine.

\section{Somatic Molecular Features for Glioma Classification}

\subsection{Molecular Features of Astrocytoma and Oligodendroglioma}

Diffuse gliomas (DGs) of the astrocytic and oligodendroglial lineages (grade II and III) are characterized by frequent IDH mutations (Figure 2A). IDH1 encodes for the isocitrate-dehydrogenase enzyme 1, which catalyzes oxidative carboxylation of isocitrate to $\alpha$-ketoglutarate, thus, generating nicotinamide adenine dinucleotide phosphate hydrogen (NADPH) [39]. Mutations in IDH1 or its homolog 2 (IDH2) have been identified as early molecular events in the development of astrocytomas and oligodendrogliomas, and they occur in various types of malignancies, including IDH-mutant 
glioblastoma (grade IV) (Figure 2A) [7,40,41]. These mutations affect the R132 codon of IDH1 or the corresponding R172 codon in its homolog IDH2 (p.R172K, p.R172W, and p.R172M) [39,41-50], which fall in catalytically-active sites of these enzymes [42,43].

A

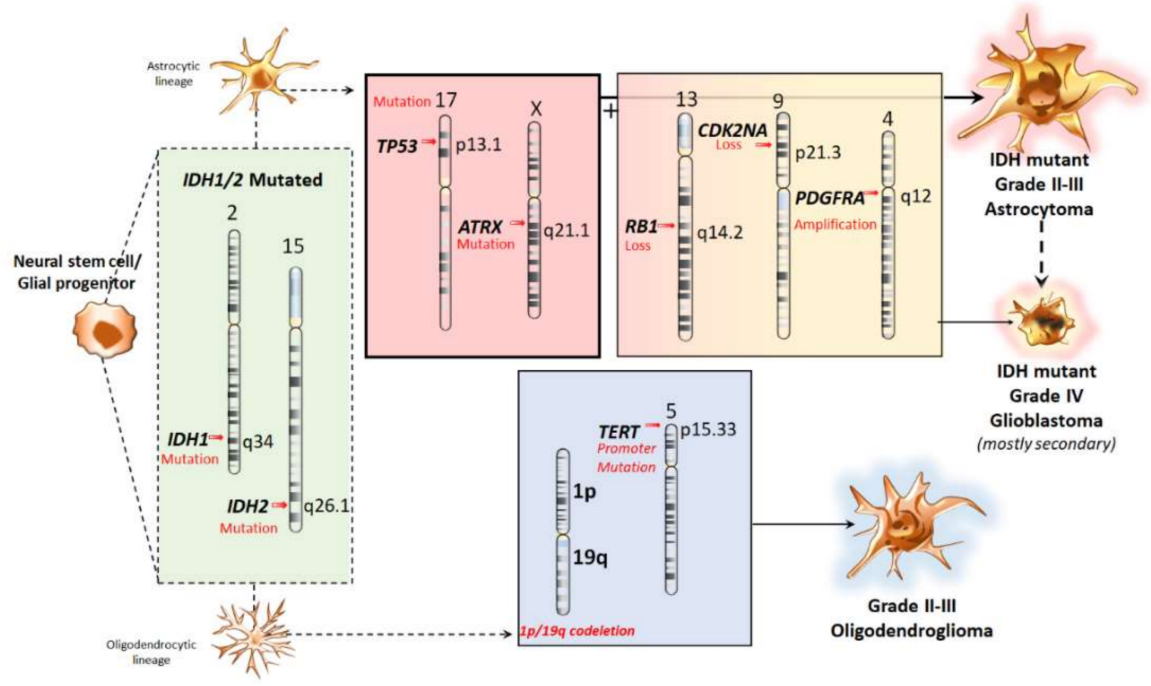

B

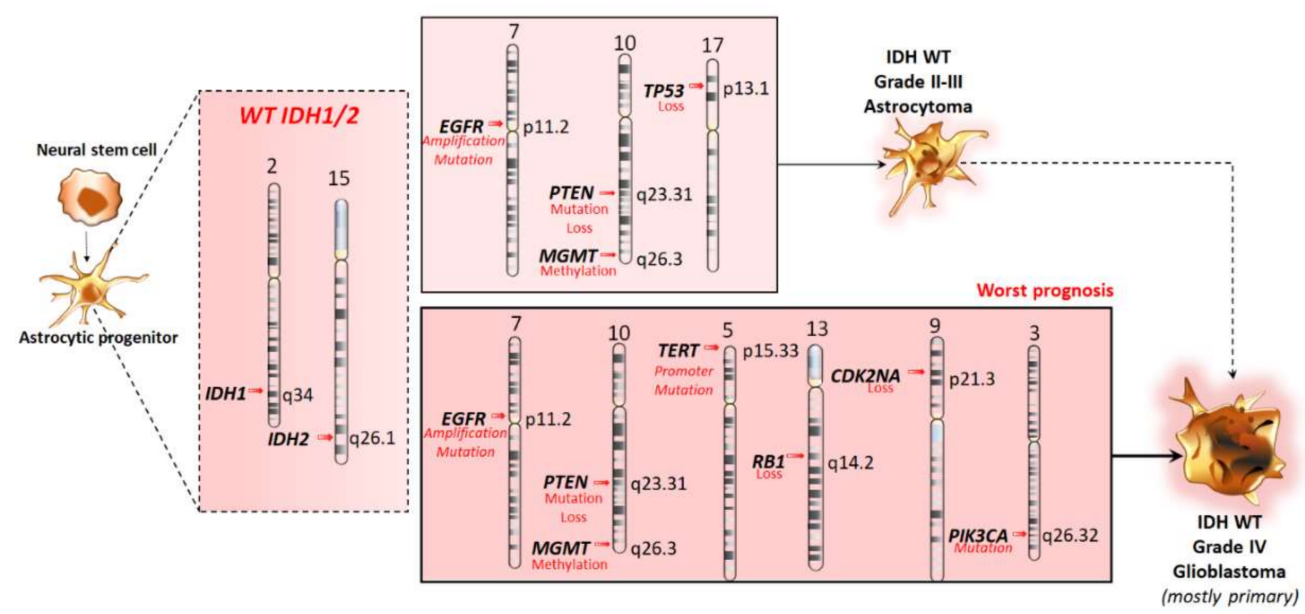

Figure 2. Genetic Biomarkers for IDH1/2-mutated (A) and IDH1/2-wild type (B) Astrocytomas and Oligodendrogliomas This cartoon roughly summarizes the main somatic gene mutations that are key in the classification of diffuse gliomas (DGs). (A). Biomarkers for astrocytomas/oligodendrogliomas featuring IDH1/2 mutations. Grade II-III astrocytomas are classified based on the occurrence of mutations within IDH1/2 along with TP53 (17p13.1) and ATRX ( $\alpha$-thalassemia mental retardation X-linked, Xq21.1). Grade IV astrocytoma (glioblastoma) arise mostly secondarily to lower-grade astrocytoma and, to a lesser extent, primarily from additional mutations occurring within $C D K N 2 A / B, R B 1$, and PDGFRA (platelet derived growth factor receptor alpha 4q12). The diagnosis of grade II-III oligodendroglioma requires the presence of a $1 p / 19 q$ codeletion and/or TERT promoter mutation besides IDH1/2 mutation. (B). Biomarkers for astrocytomas in the absence of IDH1/2 mutations. In the absence of mutations within IDH1/IDH2 genes (2q34 and 15q26.1, respectively), the classification of grade II-III and/or grade IV astrocytoma (mostly primary glioblastoma) is based on frequently occurring somatic mutations within the following genes: PIK3CA (phosphatidylinositol-4,5-bisphosphate 3-kinase catalytic subunit alpha, 3q26.32); TERT (telomerase reverse transcriptase, 5p15.33); EGFR (epidermal growth factor receptor, 7p11.2); RB1 (retinoblastoma ranscriptional orepressor 1, 13q14.2); PTEN (phosphatase and tensin homolog 10q23.31); CDKN2A/B (cyclin-dependent kinase inhibitor 2A/B, 9p21.3); TP53 (tumor protein $p 53,17$ p13.1); MGMT (O6-alkylguanine DNA alkyltransferase, 10q26.3) methylation status may serve as a predictive biomarker of chemotherapeutic susceptibility. 
Although both types of gliomas contain IDH1/2 mutations, in astrocytic gliomas, IDH mutations are typically associated with mutations in TP53 and ATRX genes [7,50] (Figure 2A). In fact, the absence of the ATRX protein and the abundance of p53 protein are required for the diagnosis of astrocytoma.

Traditional methods testing p53 status consist of p53 accumulation in the cell nuclei detected via immune-staining. Later on, sequence analysis was focused on hotspot mutations located in exons 5-8, although recent studies suggest that TP53 carries mutations also outside its mutational hotspots.

Loss-of-function mutations in ATRX (SWI/SNF chromatin re-modeler gene) co-occur with mutations in TP53 and IDH1/IDH2 genes in adults or H3.3 histone monomers genes (H3F3A and HIST1H3B) in children [51-54]. Recent papers suggest that ATRX deficiency produces deleterious effects on genomic integrity through an alternative lengthening of telomeres (ALT) that impairs the physiological arrest of cell division $[55,56]$.

Similarly to astrocytomas, oligodendrogliomas have IDH mutations associated with co-deletion of chromosomal arms 1p and 19q (Figure 2A) [54,57]. According to the 2007 WHO classification, oligodendrogliomas could be diagnosed only when typical histological features are associated with the recently defined "oligodendroglioma, $I D H$-mutant and 1p/19q codeleted", a molecular condition that requires the concomitancy of both $I D H 1$ or $I D H 2$ mutations and $1 \mathrm{p} / 19 \mathrm{q}$ co-deletion. Oligodendrogliomas often feature mutations in the Drosophila homolog of capicua transcriptional repressor (CIC) gene and the TERT promoter [54,57-59], which encodes for the catalytic subunit of telomerase [58]. The two most common mutations in the TERTp are p.C228T and p.C250T, which are located upstream of the TERT ATG start site. These mutations produce TERT activation, which is responsible for the growth properties of the tumor cells, indicating the importance of its role in cancer development $[60,61]$ (Figure 2A).

According to the WHO 2016 classification, assessment of pTERT mutation may assist histological diagnosis. In fact, in LGGs the presence of a pTERT mutation in association with IDH mutation and $1 p / 19 q$ co-deletion may represent a diagnostic surrogate for oligodendroglia lineage. Similarly, the presence of a pTERT mutation without IDH mutation and $1 \mathrm{p} / 19 \mathrm{q}$ co-deletion suggests an aggressive clinical course [62]. It is known that the effect of $p T E R T$ mutations is inversely related to mutations found in the IDH1 gene [34], and this is strongly related to a favorable prognosis [28].

\subsection{Molecular Features of Primary Glioblastomas}

The genetic heterogeneity of glioblastoma prompted a molecular characterization to identify various molecular subtypes. Primary glioblastomas typically lack IDH mutations [17], while possessing severe dysregulations of specific signaling pathways (Figure 2B). This is best exemplified by alterations in tyrosine kinase receptor (RTK)/RAS/PI(3)K signaling leading to EGFR amplification. EGFR is a proto-oncogene, which encodes for a transmembrane receptor of the ERBB family [63]. A quite common activating EGFR mutation consists of exons 2-7 deletion leading to a truncated EGFR variant III (EGFRvIII), which is often described in glioblastoma [64,65]. This deletion translates into a truncated extracellular domain with ligand-independent constitutive activity due to the loss of amino acids 6-273 producing a junction site with a new glycine residue (amino acids 5-274) [66]. Among EGFR mutants, EGFRvIII represents a late event following wild type EGFR amplification [67]. While the majority of glioblastoma cells express either EGFR or EGFRvIII, a small fraction of tumor cells co-express EGFR and EGFRvIII (Figure 2B). In addition, $24 \%$ of glioblastoma samples have point mutations in the extracellular region of EGFR which keep EGFR in active conformation $[64,65]$.

Primary glioblastomas also carry mutations in the phosphatase and tensin homolog (PTEN) gene and in the TERT promoter. In addition, monosomy of chromosome 10, gain of chromosome 7 or $7 \mathrm{q}$, and loss of $9 \mathrm{p}$ involving the $C D K N 2 A / B$ loci often occur [68].

\subsection{Glioma Epigenetics}

Over the last decade, mutations in epigenetic regulator genes have been identified as key drivers for specific subtypes of glioma with distinct clinical features [69]. This is the case of mutations in 
IDH1 or IDH2 in lower-grade gliomas, and histone 3 (H3F3A and HIST1H3B) mutations in pediatric high-grade gliomas that are also associated with specific patterns of DNA methylation [70].

The $O^{6}$-alkylguanine DNA alkyltransferase gene (MGMT), a DNA repair gene, is the most prominent epigenetic biomarker in gliomas (Figure 2B) and its alterations play a central role in GMB classification, treatment, and survival outcomes.

In line with this, MGMT methylation status has become the first predictive biomarker in neuro-oncology [20,71-76]. In fact, promoter methylation-dependent silencing of MGMT predicts sensitivity to alkylating agent therapy [73,74]. MGMT silencing may blunt therapeutic efficacy by hampering the repairs of $\mathrm{O}^{6}$-methylguanine, a toxic damage induced by alkylating agents.

Therefore, GMB patients with unmethylated MGMT do not profit much from the addition of temozolomide either as a concomitant drug or as an adjuvant to radiotherapy [20]. Routine determination of the MGMT status allows stratified treatment, thus, it should be used to select glioblastoma patients for clinical trials allowing to omit temozolomide in their treatment arm $[75,76]$.

Correlations between IDH1 mutation, MGMT promoter methylation and survival outcomes have been analyzed [77]. The role of the MGMT methylation status on benefit from temozolomide in IDH mutant (IDHmt) lower-grade gliomas is less clear [78], although most cases $(>80 \%)$ show methylation at the MGMT promoter. However, unlike glioblastomas lacking one copy of chromosome 10 where MGMT is located, IDHmt lower-grade gliomas usually retain both copies and MGMT may not be completely silenced. This results in residual repair capacity of MGMT conferring slight resistance to temozolomide therapy [79]. In routine tests, methylation-specific PCR is genererally employed to determine the MGMT methylation status [80]. An MGMT status classifier (MGMT-STP27) is available for samples analyzed at Illumina DNA methylation platform (HM27 K, HM450 K, EPIC) [81], which is routinely applied in clinical trials [82].

\section{Somatic Molecular Features and Copy Number Variation}

Recurrent Copy Number Variations (CNVs) have been reported in gliomas, where various chromosome regions are involved following several combinations, suggesting a strong genomic instability. The induction of a genomic instability phenotype is a crucial and early event in carcinogenesis [83,84].

Three types of genomic instability, namely microsatellite (MIN), chromosomal (CIN), and point mutation instability (PIN), may be manifestations of a mutator phenotype [85]. CIN is defined as an increased propensity to acquire chromosome aberrations following dysfunctional processes in chromosome replication, repair, or segregation [86].

$\mathrm{CIN}$, which represents a persistently high rate of chromosome mis-segregation, is responsible for $\mathrm{CNV}$ of whole or part of chromosomes, thus, representing a major source of genetic heterogeneity. In fact, CIN constantly causes modifications of karyotypes that result in extensive heterogeneity within cells $[87,88]$.

The $1 \mathrm{p} / 19 \mathrm{q}$ co-deletion likely represents the best characterized and most studied marker [89]. This codeletion consists of the complete deletion including both the short arm of chromosome 1 (1p) and the long arm of chromosome 19 (19q). This deletion is produced by a balanced whole-arm translocation of chromosomes $1 / 19$, which leads to the formation of two derivative chromosomes, where the chromosomes composed of $1 p$ and $19 q$ (der [1,19] [p10; q10]) is typically lost [90,91].

The $1 \mathrm{p} / 19 \mathrm{q}$ co-deletion represents the molecular marker of oligodendrogliomas, a subtype of primary brain tumors accounting for approximately $15 \%$ of all DGs in adults [92,93]. According to the 2016 WHO classification, detecting $1 \mathrm{p} / 19 \mathrm{q}$ co-deletion is essential for the neuropathology of gliomas owning an oligodendroglioma-like morphology [94]. Virtually, $1 \mathrm{p} / 19 \mathrm{q}$ co-deleted tumors harbor an accompanying IDH1/IDH2 mutation $[95,96]$. Other common molecular alterations co-occurring with $1 \mathrm{p} / 19 \mathrm{q}$ co-deletion include variants in TERT, CIC, (far upstream element-binding protein 1) FUBP1 as well as MGMT promoter methylation [56,97]. 


\section{Diagnostic Approaches and NGS Application}

In the past, molecular assays for glioma required the application of different techniques such as immunohistochemistry $(\mathrm{IH})$ with mutation-specific antibodies, conventional Sanger sequencing or pyrosequencing, fluorescence in situ hybridization (FISH), and microsatellite analyses. IH has been widely used for the detection of EGFRvIII in tumors with EGFR rearrangements, as well as for ATRX, TP53, and IDHR132.

Array comparative genomic hybridization (aCGH), a technique enabling high-resolution, genome-wide screening of CNVs, has been fundamental to detect complex genomic alterations that involve gliomagenesis, including sequence changes, CNVs, and epigenetic modifications [98].

From what is reported, it appears that multiple testing is required to support a complete diagnostic workup of glioma, where biomarkers can be individually assessed by different techniques. Unfortunately, this implies that analyses of each biomarker need to be carried out sequentially, making the process time-consuming [99].

Therefore, diagnostics of gliomas, which, according to the WHO 2016 classification, also includes the assay of $\mathrm{CNVs}$, has prompted novel strategies enabling the concomitant analysis of several biomarkers. In the last years, NGS-based approaches were progressively used in the diagnosis of gliomas considering those genes that are commonly altered. When applying NGS assay for the routine diagnosis of CNS tumours, several issues need to be considered: (i) The assay should identify single nucleotide variations, insertions and deletions, complex genetic alterations (gene fusions, CNVs) in a set of genes, and mutational hotspots. (ii) The analysis should be reliable in formalin-fixed paraffin-embedded (FFPE) tissues. (iii) The assay should require a minimal amount of DNA/RNA since resection is not feasible in many patients [17].

To this aim, several targeted NGS panels were implemented for selected genetic regions, focused on point mutations, insertions and deletions, CNV changes, and gene fusions [100-102].

Nikiforova et al. set up a single workflow analyzing 30 genes for SNVs and indels, 24 genes for CNVs, and 14 types of structural alterations in BRAF, EGFR, and FGFR3 genes [17]. Ballester et al. used a more extensive NGS panel of 50 genes, and found that the most clinically relevant genes were IDH1, IDH2, TP53, PIK3CA, BRAF, EGFR, PDGFRA, and FGFR1/2/3 [103].

Zacher et al. used a 20-gene panel for an integrated histological and molecular diagnosis of 111 diffuse gliomas, allowing a re-classification of oligoastrocytoma and glioblastoma by $I D H$-status and identification of tumours with H3F3A mutations [104].

Although these approaches based on selected genes represent a promising diagnostic tool in clinical routine, they show a limitation in detecting rare genetic aberrations that are known to contribute to the pathogenesis of gliomas. This is the case of tuberous sclerosis 1 /hamartin (TSC1) or tuberous sclerosis 2/tuberin (TSC2) mutations occurring in subependymal giant cell astrocytomas [105], as well as $\mathrm{H} 3$ histone family member $\mathrm{A} / \mathrm{B}(\mathrm{HIST} 1 H 3 \mathrm{~A} / \mathrm{B})$ and activin receptor type 1 (ACVR1) mutations in diffuse intrinsic pontine gliomas [106,107].

To improve the identification of rare variants, Virk et al. analyzed the coding sequences of 409 genes implicated in cancer. Unfortunately, variants were identified in 13 (3\%) out of the 409 genes, suggesting a futility in assaying too many genes [108].

These approaches, considering targeted or extended genes panel, reliably assess key mutations such as CNVs, including $1 \mathrm{p} / 19 \mathrm{q}$ codeletion and EGFR gene amplification, CDKN2A homozygous deletion, and PTEN loss [109]. Despite a number of advantages, NGS carries inherent limits for specific biomarkers such as loss of ATRX expression; in this respect NGS may have sometimes less sensitivity than IH.

\section{Liquid Biopsies in Patients With Diffuse Glioma}

The term Circulating Nucleic Acids refers to segments of DNA/RNA found in the bloodstream or other body fluids. These molecules were identified as all cell-free entities, attached to lipid or protein structures, and as the content of circulating extracellular vesicles (EVs) and blood platelets [110,111]. 
Cancer cells release circulating tumor DNA (ctDNA) through yet unclear mechanisms, although apoptosis or necroptosis are suggested to be the principal source [112-114]. The analysis of ctDNA and other nucleic acids in body fluids is also known as "Liquid Biopsy". This approach considers the blood as the main source of ctDNA since serum shows higher background levels probably due to contamination with DNA that is released from immune cells lysing during the clotting process. Therefore, plasma is generally preferable to serum [114].

In support of this, ctDNA has been detected, analyzed, and quantified in plasma of patients with different types of cancer [114-116]. Tagged-amplicon deep sequencing (TAm-Seq) allowed detecting blood-ctDNA mutations in about $2 \%$ of gliomas [115]. The most common variants detected in the blood-ctDNA of glioma patients are IDH1, EGFR, $p 53$, and PTEN [114]. Nonetheless, the identification of ctDNA in the blood of patients with primary brain tumours is challenging due to the presence of the blood-brain barrier (BBB), which may impede the free circulation of DNA [116-118]. Therefore, the use of alternative fluids such as the cerebrospinal fluid (CSF) may provide an alternative way to genotype gliomas [117].

To this aim, Wang et al. analyzed 35 primary CNS malignancies using targeted or genome-wide sequencing. They detected CSF-ctDNA in $74 \%$ of cases, and mutations were detected in each patient [118]. De Mattos-Arruda et al. found mutations in IDH1/2, EGFR, PTEN, FGFR2, and ERBB2 genes, and they showed that CSF-ctDNA undergoes dynamic changes that are correlated with the treatment course of patients with glioblastoma [117]. Recently, the presence of ctDNA was detected in about $50 \%$ of 85 patients with gliomas, and it was associated with disease burden and adverse outcome [119]. This study demonstrated that the genomic features of ctDNA in CSF from patients with gliomas closely resembled the genomes of tumour biopsies. In this scenario, liquid biopsy allows monitoring the evolution of the cancer genome through a minimally invasive technique, which may provide, in the future, the opportunity of genotype-directed therapies for gliomas.

Of relevance, ctDNA could be used to identify the methylation status of gene promoters involved in CNS tumors. Indeed, in both CSF and tissue from glioblastoma patients, Chen et al. identified promoter hypomethylation of MGMT, p16INK4a, TIMP-3, and THBS1 genes [120].

Liquid biopsy has allowed identifying additional components in the CSF of glioblastoma patients. This is the case of CSF-isolated EVs which allowed the detection of IDH1 mutations in five out of eight patients using beads, emulsion, amplification, magnetics (BEAMing) and Droplet Digital PCR (ddPCR) techniques. These outcomes match with the corresponding IDH1 mutations detected in tumor tissues [121]. In addition, circulating as well as EV-derived miRNAs have been detected in CSF samples $[122,123]$, suggesting that they might serve as CSF biomarkers to diagnose and monitor therapy response in glioblastoma patients [124]. In support of this, the levels of a panel of nine miRNAs detected in the CSF of glioblastoma patients, including miR-21, miR-218, miR-193b, miR-331, miR374a, miR548c, miR520f, miR27b, and miR-30b, were found to correlate with those detected from tissue biopsies [125].

\section{Merging Genomics and Immunology: A Glance at Future Perspectives}

Investigating the expression patterns and clinical characteristics of immune checkpoint proteins as well as the specific genomic alterations that produce immunogenic neo-antigens/peptides may be helpful for expanding our understanding of antitumor immunotherapy in gliomas [126,127]. Indeed, this is the era of personalized medicine where the marriage between genomics and immunology dictates the successes of immunotherapy in cancer, from checkpoint inhibitors to CAR T cells [126,127].

Recently, 41 immune prognostic genes were identified in glioma patients based on the IDH1 mutation status [128]. High-risk LGG patients express high levels of (CD28/cytotoxic T-lymphocyte-associated protein 4) CTLA-4 and programmed death protein-1 (PD-1), and they possess high levels of infiltrating B cells, CD4+ T cells, CD8+ T cells, neutrophils, macrophages, and dendritic cells [128]. CTLA-4 is an immune checkpoint protein that negatively regulates $\mathrm{T}$ cell-mediated immune responses. Higher expression levels of CTLA-4 occur in patients with higher grade IDH-wt 
gliomas compared with patients bearing lower grade, IDH-mt gliomas [126]. A positive correlation exists between CTLA-4 expression and specific marker genes of immune cells, including CD8 ${ }^{+}$ $\mathrm{T}$ cells, regulatory $\mathrm{T}$ cells, and macrophages. Thus, the higher the CTLA-4 expression in the glioma microenvironment, the greater the immune cell infiltration, and the worse the prognosis. In fact, patients with glioma possessing lower CTLA-4 expression levels exhibit significantly longer overall survival [126].

In glioma patients, a correlation has also been identified among EGFR mutation, shorter survival time and increased infiltration of immune cells along with PD-L1 expression [129]. Programmed death-ligand 1 (PD-L1) is the ligand of PD-1, a cell surface receptor belonging to the extended CTLA-4 family of T cell regulators. As recently reviewed, the expression levels of PD-L1 are positively correlated with glioma grades and negatively correlated with the prognosis of glioma patients [130]. PD-L1 levels are also associated with glioma genotypes, with PD-L1 expression being significantly lower in IDH-mt compared with IDH-wt gliomas [130]. In detail, PD-L1 expression is negatively correlated with PD-L1 promoter methylation level, which is consistently higher in IDH-mt compared to IDH-wt gliomas [130].

Thus, classifying glioma patients into subgroups based on distinct immunophenotypes, genotypes, and outcomes may be a clinically promising biomarker, which may improve prognosis and foster personalized therapies for gliomas.

\section{Conclusions}

Genetic analysis is key to identify molecular features of glioma tissue, to identify germline loci that contribute to individual risk for tumor development, and to select potential biomarkers useful for clinical applications.

Except for a few rare mendelian cancer predisposition syndromes, the genetic basis of inherited susceptibility to gliomas is currently undefined since none of the germline loci clearly confer an increased risk of developing the disease. On the contrary, somatic mutations identified within the tissue define tumor genotype as well as glioma subtypes, focusing on dysregulated pathways that can be either common or specific to a subset of cancers.

These molecular markers may overwrite the histologic phenotype, thus, representing a valid diagnostic and prognostic markers for glioma classification and guided therapy. To date, most data have been produced by using several molecular approaches like Sanger sequencing or pyrosequencing, fluorescence in-situ hybridization, microsatellite analyses and immunohistochemistry. In the last years, the implementation of NGS has revolutionized our understanding of cancer somatic genome changes, as well as the inter- and intra-individual heterogeneity of tumors. This technique is now under evaluation as an all-in-one diagnostic tool aimed at detecting both DNA copy number variations and mutations in glioma. NGS approaches based on selected genes represent a promising diagnostic tool in clinical routine; yet, they show a limitation in detecting rare genetic aberrations that are known to contribute to the pathogenesis of gliomas. Unfortunately, protocols based on the evaluation of hundreds of genes witness for futility in assaying too many genes. Despite a number of advantages, NGS carries inherent limits for specific biomarkers, showing less sensitivity than IH.

NGS approach is also widely used in Liquid Biopsy to detect ctDNA within the CSF from patients affected by primary brain tumors. Such an approach is providing an alternative cost-effective approach to genotype all gliomas, while avoiding surgical tissue collection and repeated tumor biopsies. CSF-ctDNA undergoes dynamic changes in CSF which are correlated with the treatment outcomes of patients with glioma, and genomic features of glioma CSF-ctDNA closely resemble the genomes of tumour biopsies. In this scenario, liquid biopsy allows monitoring the evolution of the glioma genome through a minimally invasive technique, giving the future opportunity of genotype-directed, tailored therapy for glioma patients. In this context, the marriage between genomics and the immune system may provide clinically revelant biomarkers improving glioma patients' stratification and treatment. 
Author Contributions: Original Draft Preparation, Writing, Review, and Art Work, F.L. and S.G.; Review, Editing, and Art Work, A.A., R.F., and F.B.; Conceptualization, M.F., M.S. and M.A.O.; Supervision, F.F. All authors have read and agreed to the published version of the manuscript.

Funding: This work was funded by the Ministero della Salute (Ricerca Corrente 2018-2020).

Conflicts of Interest: The authors declare no conflict of interest.

\section{Abbreviations}

\begin{tabular}{|c|c|}
\hline $\mathrm{aCGH}$ & Array Comparative Genomic Hybridization \\
\hline ACVR1 & Activin Receptor Type 1 \\
\hline ALT & Alternative Lengthening Of Telomeres \\
\hline $\operatorname{ATRX} \alpha-$ & Thalassemia Mental Retardation X-Linked \\
\hline $\mathrm{BBB}$ & Blood-Brain Barrier \\
\hline CDKN2A, CDKN2B & Cyclin-Dependent Kinase Inhibitor 2A And B \\
\hline $\mathrm{CIC}$ & Capicua Transcriptional Repressor \\
\hline CIN & Chromosomal Instability \\
\hline CNS & Central Nervous System \\
\hline CNVs & Copy Number Variations \\
\hline CSF & Cerebrospinal Fluid \\
\hline ctDNSA & Circulating Tumor DNA \\
\hline ddPCR & Droplet-Based Digital PCR \\
\hline EGFR & Epidermal Growth Factor Receptor \\
\hline EVs & Circulating Extracellular Vesicles \\
\hline FFPE & Formalin-Fixed Paraffin-Embedded \\
\hline FISH & Fluorescence In Situ Hybridization \\
\hline GWAS & Genome-Wide Association Studies \\
\hline IDH1 & I Isocitrate-Dehydrogenase Enzyme 1 \\
\hline IDH2 & Isocitrate-Dehydrogenase Enzyme 2 \\
\hline $\mathrm{IH}$ & Immunohistochemistry \\
\hline LGGs & Low-Grade Gliomas \\
\hline MGMT DNA & Repair Gene O6-Alkylguanine DNA Alkyltransferase \\
\hline MIN & Microsatellite Instability \\
\hline NADPH & Nicotinamide Adenine Dinucleotide Phosphate \\
\hline NGS & Next Generation Sequencing \\
\hline OPN & Osteopontin \\
\hline PHLDB1 & Pleckstrin Homology-Like Domain Family B Member 1 \\
\hline PIN & Point Mutation Instability \\
\hline PTEN & Phosphatase And Tensin Homolog \\
\hline RTEL1 & Regulator of Telomere Elongation Helicase 1 \\
\hline SNVs & Single Nucleotide Variations \\
\hline TERT & Telomerase Reverse Transcriptase \\
\hline TP53 & Tumor Protein P53 \\
\hline TP534 & Tumor Protein P53 \\
\hline TSC1 & Tuberous Sclerosis 1/Hamartin \\
\hline TSC2 & Tuberous Sclerosis 2/Tuberin \\
\hline VEGF & Vascular Endothelial Growth Factor \\
\hline WHO & World Health Organization \\
\hline
\end{tabular}




\section{References}

1. Vigneswaran, K.; Neill, S.; Hadjipanayis, C.G. Beyond the World Health Organization grading of infiltrating gliomas: Advances in the molecular genetics of glioma classification. Ann. Transl. Med. 2015, 3, 95.

2. Louis, D.N.; Ohgaki, H.; Wiestler, O.D.; Cavenee, W.K. (Eds.) WHO Classification of Tumours of the Central Nervous System, 4th ed.; IARC: Lyon, France; WHO Regional Office Europe: Copenhagen, Denmark, 2007; pp. 33-49.

3. Louis, D.N.; Perry, A.; Reifenberger, G.; Von Deimling, A.; Figarella-Branger, D.; Cavenee, W.K.; Ohgaki, H.; Wiestler, O.D.; Kleihues, P.; Ellison, D.W. The 2016 World Health Organization Classification of Tumors of the Central Nervous System: A summary. Acta Neuropathol. 2016, 131, 803-820. [CrossRef]

4. Stupp, R.; Mason, W.P.; van den Bent, M.J.; Weller, M.; Fisher, B.; Taphoorn, M.J.; Belanger, K.; Brandes, A.A.; Marosi, C.; Bogdahn, U.; et al. Radiotherapy plus concomitant and adjuvant temozolomide for glioblastoma. N. Engl. J. Med. 2005, 352, 987-996. [CrossRef] [PubMed]

5. Wen, P.Y.; Kesari, S. Malignant gliomas in adults. N. Engl. J. Med. 2008, 359, 492-507. [CrossRef] [PubMed]

6. Ohgaki, H.; Kleihues, P. The definition of primary and secondary glioblastoma. Clin. Cancer Res. 2013, 19, 764-772. [CrossRef] [PubMed]

7. Cancer Genome Atlas Research. Network Comprehensive genomic characterization defines human glioblastoma genes and core pathways. Nature 2008, 455, 1061-1068. [CrossRef] [PubMed]

8. Sottoriva, A.; Spiteri, I.; Piccirillo, S.G.; Touloumis, A.; Collins, V.P.; Marioni, J.C.; Curtis, C.; Watts, C.; Tavaré, S. Intratumor heterogeneity in human glioblastoma reflects cancer evolutionary dynamics. Proc. Natl. Acad. Sci. USA 2013, 110, 4009-4014. [CrossRef] [PubMed]

9. Nickel, G.C.; Barnholtz-Sloan, J.; Gould, M.P.; McMahon, S.; Cohen, A.; Adams, M.D.; Guda, K.; Cohen, M.; Sloan, A.E.; LaFramboise, T. Characterizing mutational heterogeneity in a glioblastoma patient with double recurrence. PLoS ONE 2013, 7, e35262. [CrossRef] [PubMed]

10. Phillips, H.S.; Kharbanda, S.; Chen, R.; Forrest, W.F.; Soriano, R.H.; Wu, T.D.; Misra, A.; Nigro, J.M.; Colman, H.; Soroceanu, L.; et al. Molecular subclasses of high-grade glioma predict prognosis, delineate a pattern of disease progression, and resemble stages in neurogenesis. Cancer Cell 2006, 9, 157-173. [CrossRef]

11. Verhaak, R.G.; Hoadley, K.A.; Purdom, E.; Wang, V.; Qi, Y.; Wilkerson, M.D.; Miller, C.R.; Ding, L.; Golub, T.; Mesirov, J.P.; et al. Integrated genomic analysis identifies clinically relevant subtypes of glioblastoma characterized by abnormalities in PDGFRA, IDH1, EGFR, and NF1. Cancer Cell 2010, 17, 98-110. [CrossRef]

12. Lawrence, M.S.; Stojanov, P.; Mermel, C.H.; Robinson, J.T.; Garraway, L.A.; Golub, T.R.; Meyerson, M.; Gabriel, S.B.; Lander, E.S.; Getz, G. Discovery and saturation analysis of cancer genes across 21 tumour types. Nature 2014, 505, 495-501. [CrossRef] [PubMed]

13. Ciriello, G.; Miller, M.L.; Aksoy, B.A.; Senbabaoglu, Y.; Schultz, N.; Sander, C. Emerging landscape of oncogenic signatures across human cancers. Nat. Genet. 2013, 45, 1127-1133. [CrossRef] [PubMed]

14. Kandoth, C.; McLellan, M.D.; Vandin, F.; Ye, K.; Niu, B.; Lu, C.; Xie, M.; Zhang, Q.; McMichael, J.F.; Wyczalkowski, M.A.; et al. Mutational landscape and significance across 12 major cancer types. Nature 2013, 502, 333-339. [CrossRef] [PubMed]

15. Ostrom, Q.T.; Gittleman, H.; Liao, P.; Rouse, C.; Chen, Y.; Dowling, J.; Wolinsky, Y.; Kruchko, C.; Barnholtz-Sloan, J. CBTRUS statistical report: Primary brain and central nervous system tumors diagnosed in the United States in 2007-2011. Neuro Oncol. 2014, 16 (Suppl 4), iv1-iv63. [CrossRef]

16. Wood, M.D.; Halfpenny, A.M.; Moore, S.R. Applications of molecular neuro-oncology-a review of diffuse glioma integrated diagnosis and emerging molecular entities. Diagn. Pathol. 2019, 14, 29. [CrossRef]

17. Nikiforova, M.N.; Hamilton, R.L. Molecular diagnostics of gliomas. Arch. Pathol. Lab. Med. 2011, 135, 558-568.

18. Ducray, F.; El Hallani, S.; Idbaih, A. Diagnostic and prognostic markers in gliomas. Curr. Opin. Oncol. 2009, 21, 537-542. [CrossRef]

19. Riemenschneider, M.J.; Jeuken, J.W.; Wesseling, P.; Reifenberger, G. Molecular diagnostics of gliomas: State of the art. Acta Neuropathol. 2010, 120, 567-584. [CrossRef]

20. Hegi, M.E.; Diserens, A.C.; Gorlia, T.; Hamou, M.F.; de Tribolet, N.; Weller, M.; Kros, J.M.; Hainfellner, J.A.; Mason, W.; Mariani, L.; et al. MGMT gene silencing and benefit from temozolomide in glioblastoma. N. Engl. J. Med. 2005, 352, 997-1003. [CrossRef] 
21. Houillier, C.; Wang, X.; Kaloshi, G.; Mokhtari, K.; Guillevin, R.; Laffaire, J.; Paris, S.; Boisselier, B.; Idbaih, A.; Laigle-Donadey, F.; et al. IDH1 or IDH2 mutations predict longer survival and response to temozolomide in low-grade gliomas. Neurology 2010, 75, 1560-1566. [CrossRef]

22. Hemminki, K.; Li, X. Familial risks in nervous system tumors. Cancer Epidemiol. Biomark. Prev. 2003, 12, 1137-1142.

23. Kinnersley, B.; Labussiere, M.; Holroyd, A.; Di Stefano, A.L.; Broderick, P.; Vijayakrishnan, J.; Mokhtari, K.; Delattre, J.Y.; Gousias, K.; Schramm, J.; et al. Genome-wide association study identifies multiple susceptibility loci for glioma. Nat. Commun. 2015, 6, 8559. [CrossRef] [PubMed]

24. Melin, B.S.; Barnholtz-Sloan, J.S.; Wrensch, M.R.; Johansen, C.; Il’Yasova, D.; Kinnersley, B.; Ostrom, Q.T.; Labreche, K.; Chen, Y.; Armstrong, G.; et al. Genome-wide association study of glioma subtypes identifies specific differences in genetic susceptibility to glioblastoma and non-glioblastoma tumors. Nat. Genet. 2017, 49, 789. [CrossRef] [PubMed]

25. Rajaraman, P.; Melin, B.S.; Wang, Z.; McKean-Cowdin, R.; Michaud, D.S.; Wang, S.S.; Bondy, M.; Houlston, R.; Jenkins, R.B.; Wrensch, M.; et al. Genome-wide association study of glioma and meta-analysis. Hum. Genet. 2012, 131, 1877-1888. [CrossRef] [PubMed]

26. Sanson, M.; Hosking, F.J.; Shete, S.; Zelenika, D.; Dobbins, S.E.; Ma, Y.; Enciso-Mora, V.; Idbaih, A.; Delattre, J.Y.; Hoang-Xuan, K.; et al. Chromosome 7p11.2 (EGFR) variation influences glioma risk. Hum. Mol. Genet. 2011, 20, 2897-2904. [CrossRef]

27. Shete, S.; Hosking, F.J.; Robertson, L.B.; Dobbins, S.E.; Sanson, M.; Malmer, B.; Simon, M.; Marie, Y.; Boisselier, B.; Delattre, J.Y.; et al. Genome-wide association study identifies five susceptibility loci for glioma. Nat. Genet. 2009, 41, 899-904. [CrossRef]

28. Wrensch, M.; Jenkins, R.B.; Chang, J.S.; Yeh, R.F.; Xiao, Y.; Decker, P.A.; Ballman, K.V.; Berger, M.; Buckner, J.C.; Chang, S.; et al. Variants in the CDKN2B and RTEL1 regions are associated with high-grade glioma susceptibility. Nat. Genet. 2009, 41, 905-908. [CrossRef]

29. Enciso-Mora, V.; Hosking, F.J.; Di Stefano, A.L.; Zelenika, D.; Shete, S.; Broderick, P.; Idbaih, A.; Delattre, J.Y.; Hoang-Xuan, K.; Marie, Y.; et al. Low penetrance susceptibility to glioma is caused by the TP53 variant rs78378222. Br. J. Cancer 2013, 108, 2178-21785. [CrossRef]

30. Jenkins, R.B.; Xiao, Y.; Sicotte, H.; Decker, P.A.; Kollmeyer, T.M.; Hansen, H.M.; Kosel, M.L.; Zheng, S.; Walsh, K.M.; Rice, T.; et al. A low-frequency variant at 8q24.21 is strongly associated with risk of oligodendroglial tumors and astrocytomas with IDH1 or IDH2 mutation. Nat. Genet. 2012, 44, 1122-1125. [CrossRef]

31. Enciso-Mora, V.; Hosking, F.J.; Kinnersley, B.; Wang, Y.; Shete, S.; Zelenika, D.; Broderick, P.; Idbaih, A.; Delattre, J.Y.; Hoang-Xuan, K.; et al. Deciphering the 8q24.21 association for glioma. Hum. Mol. Genet. 2013, 22, 2293-2302. [CrossRef]

32. Walsh, K.M.; Codd, V.; Smirnov, I.V.; Rice, T.; Decker, P.A.; Hansen, H.M.; Kollmeyer, T.; Kosel, M.L.; Molinaro, A.M.; McCoy, L.S.; et al. Variants near TERT and TERC influencing telomere length are associated with high-grade glioma risk. Nat. Genet. 2014, 46, 731-735. [CrossRef] [PubMed]

33. Malmer, B.; Iselius, L.; Holmberg, E.; Collins, A.; Henriksson, R.; Gronberg, H. Genetic epidemiology of glioma. Br. J. Cancer 2001, 84, 429-434. [CrossRef] [PubMed]

34. De Andrade, M.; Barnholtz, J.S.; Amos, C.I.; Adatto, P.; Spencer, C.; Bondy, M.L. Segregation analysis of cancer in families of glioma patients. Genet. Epidemiol. 2001, 20, 258-270. [CrossRef]

35. Stacey, S.N.; Sulem, P.; Jonasdottir, A.; Masson, G.; Gudmundsson, J.; Gudbjartsson, D.F.; Magnusson, O.T.; Gudjonsson, S.A.; Sigurgeirsson, B.; Thorisdottir, K.; et al. A germline variant in the TP53 polyadenylation signal confers cancer susceptibility. Nat. Genet. 2011, 43, 1098-1103. [CrossRef]

36. Schwartzbaum, J.A.; Xiao, Y.; Liu, Y.; Tsavachidis, S.; Berger, M.S.; Bondy, M.L.; Chang, J.S.; Chang, S.M.; Decker, P.A.; Ding, B.; et al. Inherited variation in immune genes and pathways and glioblastoma risk. Carcinogenesis 2010, 31, 1770-1777. [CrossRef]

37. Andersson, U.; Schwartzbaum, J.; Wiklund, F.; Sjostrom, S.; Liu, Y.; Tsavachidis, S.; Ahlbom, A.; Auvinen, A.; Collatz-Laier, H.; Feychting, M.; et al. A comprehensive study of the association between the EGFR and ERBB2 genes and glioma risk. Acta Oncol. 2010, 49, 767-775. [CrossRef]

38. Liu, Y.; Shete, S.; Hosking, F.J.; Robertson, L.B.; Bondy, M.L.; Houlston, R.S. New insights into susceptibility to glioma. Arch. Neurol. 2010, 67, 275-278. [CrossRef]

39. Deng, L.; Xiong, P.; Luo, Y.; Bu, X.; Qian, S.; Zhong, W.; Lv, S. Association between IDH1/2 mutations and brain glioma grade. Oncol. Lett. 2018, 1, 5405-5409. [CrossRef] 
40. Molenaar, R.J.; Verbaan, D.; Lamba, S.; Zanon, C.; Jeuken, J.W.; Boots-Sprenger, S.H.; Wesseling, P.; Hulsebos, T.J.; Troost, D.; van Tilborg, A.A.; et al. The combination of IDH1 mutations and MGMT methylation status predicts survival in glioblastoma better than either IDH1 or MGMT alone. Neuro Oncol. 2014, 16, 1263-1273. [CrossRef]

41. Yan, H.; Parsons, D.W.; Jin, G.; McLendon, R.; Rasheed, B.A.; Yuan, W.; Kos, I.; Batinic-Haberle, I.; Jones, S.; Riggins, G.J.; et al. IDH1 and IDH2 mutations in gliomas. N. Engl. J. Med. 2009, 360, 765-773. [CrossRef]

42. Balss, J.; Meyer, J.; Mueller, W.; Korshunov, A.; Hartmann, C.; von Deimling, A. Analysis of the IDH1 codon 132 mutation in brain tumors. Acta Neuropathol. 2008, 116, 597-602. [CrossRef] [PubMed]

43. Ichimura, K.; Pearson, D.M.; Kocialkowski, S.; Bäcklund, L.M.; Chan, R.; Jones, D.T.; Collins, V.P. IDH1 mutations are present in the majority of common adult gliomas but rare in primary glioblastomas. Neuro Oncol. 2009, 11, 341-347. [CrossRef] [PubMed]

44. Horbinski, C. What do we know about IDH1/2 mutations so far, and how do we use it? Acta Neuropathol. 2013, 125, 621-636. [CrossRef] [PubMed]

45. Hong, S.P.; Wen, J.; Bang, S.; Park, S.; Song, S.Y. CD44-positive cells are responsible for gemcitabine resistance in pancreatic cancer cells. Int. J. Cancer 2009, 125, 2323-2331. [CrossRef] [PubMed]

46. Hagmann, W.; Jesnowski, R.; Faissner, R.; Guo, C.; Lohr, J.M. ATPbinding cassette C transporters in human pancreatic carcinoma cell lines. Upregulation in 5-fluorouracil-resistant cells. Pancreatology 2009, 9, 136-144. [PubMed]

47. Cui, Y.; Ko“nig, J.; Buchholz, J.K.; Spring, H.; Leier, I.; Keppler, D. Drug resistance and ATP-dependent conjugate transport mediated by the apical multidrug resistance protein, MRP2, permanently expressed in human and canine cells. Mol. Pharmacol. 1999, 55, 929-937.

48. Oguri, T.; Bessho, Y.; Achiwa, H.; Ozasa, H.; Maeno, K.; Maeda, H.; Sato, S.; Ueda, R. MRP8/ABCC11 directly confers resistance to 5-fluorouracil. Mol. Cancer Ther. 2007, 6, 122-127. [CrossRef]

49. Pratt, S.; Shepard, R.L.; Kandasamy, R.A.; Johnston, P.A.; Perry, W.; Dantzig, A.H. The multidrug resistance protein 5 (ABCC5) confers resistance to 5-fluorouracil and transports its monophosphorylated metabolites. Mol. Cancer Ther. 2005, 4, 855-863. [CrossRef]

50. Kieran, M.W.; Roberts, C.W.; Chi, S.N.; Ligon, K.L.; Rich, B.E.; Macconaill, L.E.; Garraway, L.A.; Biegel, J.A. Absence of oncogenic canonical pathway mutations in aggressive pediatric rhabdoid tumors. Pediatr. Blood Cancer 2012, 59, 1155-1157. [CrossRef]

51. Jiao, Y.; Killela, P.J.; Reitman, Z.J.; Rasheed, A.B.; Heaphy, C.M.; de Wilde, R.F.; Rodriguez, F.J.; Rosemberg, S.; Oba-Shinjo, S.M.; Nagahashi Marie, S.K.; et al. Frequent ATRX, CIC, FUBP1 and IDH1 mutations refine the classification of malignant gliomas. Oncotarget 2012, 3, 709-722. [CrossRef]

52. Kannan, K.; Inagaki, A.; Silber, J.; Gorovets, D.; Zhang, J.; Kastenhuber, E.R.; Heguy, A.; Petrini, J.H.; Chan, T.A.; Huse, J.T.; et al. Whole exome sequencing identified ATRX mutation as a key molecular determinant in lower-grade glioma. Oncotarget 2012, 3, 1194-1203. [CrossRef] [PubMed]

53. Schwartzentruber, J.; Korshunov, A.; Liu, X.Y.; Jones, D.T.; Pfaff, E.; Jacob, K.; Sturm, D.; Fontebasso, A.M.; Quang, D.A.; Tönjes, M.; et al. Driver mutations in histone H3.3 and chromatin remodelling genes in paediatric glioblastoma. Nature 2012, 482, 226-231. [CrossRef] [PubMed]

54. Brat, D.J.; Verhaak, R.G.; Aldape, K.D.; Yung, W.K.; Salama, S.R.; Cooper, L.A.; Rheinbay, E.; Miller, C.R.; Vitucci, M.; et al.; Cancer Genome Atlas Research Network Comprehensive, Integrative Genomic Analysis of Diffuse Lower-Grade Gliomas. N. Engl. J. Med. 2015, 372, 2481-2498. [PubMed]

55. Clynes, D.; Jelinska, C.; Xella, B.; Ayyub, H.; Scott, C.; Mitson, M.; Taylor, S.; Higgs, D.R.; Gibbons, R.J. Suppression of the alternative lengthening of telomere pathway by the chromatin remodelling factor ATRX. Nat. Commun. 2015, 6, 753. [CrossRef]

56. Heaphy, C.M.; de Wilde, R.F.; Jiao, Y.; Klein, A.P.; Edil, B.H.; Shi, C.; Bettegowda, C. Altered telomeres in tumors with ATRX and DAXX mutations. Science 2011, 333, 425. [CrossRef]

57. Suzuki, H.; Aoki, K.; Chiba, K.; Sato, Y.; Shiozawa, Y.; Shiraishi, Y.; Shimamura, T.; Niida, A.; Motomura, K.; Ohka, F.; et al. Mutational landscape and clonal architecture in grade II and III gliomas. Nat. Genet. 2015, 47, 458-468. [CrossRef]

58. Liu, T.; Yuan, X.; Xu, D. Cancer-Specific Telomerase Reverse Transcriptase (TERT) Promoter Mutations: Biological and Clinical Implications. Genes 2016, 7, 3. [CrossRef]

59. Killela, P.J.; Reitman, Z.J.; Jiao, Y.; Bettegowda, C.; Agrawal, N.; Diaz, L.A., Jr.; Friedman, A.H.; Friedman, H.; Gallia, G.L.; Giovanella, B.C.; et al. TERT promoter mutations occur frequently in gliomas and a subset of 
tumors derived from cells with low rates of self-renewal. Proc. Natl. Acad. Sci. USA 2013, 110, 6021-6026. [CrossRef]

60. Andersson, U.; Osterman, P.; Sjostrom, S.; Johansen, C.; Henriksson, R.; Brannstrom, T.; Broholm, H.; Christensen, H.C.; Ahlbom, A.; Auvinen, A.; et al. MNS16A minisatellite genotypes in relation to risk of glioma and meningioma and to glioblastoma outcome. Int. J. Cancer 2009, 125, 968-972. [CrossRef]

61. Chiba, K.; Johnson, J.Z.; Vogan, J.M.; Wagner, T.; Boyle, J.M.; Hockemeyer, D. Cancer-associated TERT promoter mutations abrogate telomerase silencing. Elife 2015, 4, e07918. [CrossRef]

62. Guo, C.; Pirozzi, C.J.; Lopez, G.Y.; Yan, H. Isocitrate dehydrogenase mutations in gliomas: Mechanisms, biomarkers and therapeutic target. Curr. Opin. Neurol. 2011, 24, 648-652. [CrossRef] [PubMed]

63. Arteaga, C.L.; Engelman, J.A. ERBB receptors: From oncogene discovery to basic science to mechanism-based cancer therapeutics. Cancer Cell 2014, 25, 282-303. [CrossRef] [PubMed]

64. Furnari, F.B.; Cloughesy, T.F.; Cavenee, W.K.; Mischel, P.S. Heterogeneity of epidermal growth factor receptor signalling networks in glioblastoma. Nat. Rev. Cancer 2015, 15, 302-310. [CrossRef] [PubMed]

65. Brennan, C.W.; Verhaak, R.G.; McKenna, A.; Campos, B.; Noushmehr, H.; Salama, S.R.; Zheng, S.; Chakravarty, D.; Sanborn, J.Z.; Berman, S.H.; et al. The somatic genomic landscape of glioblastoma. Cell 2013, 155, 462-477. [CrossRef] [PubMed]

66. Sugawa, N.; Ekstrand, A.J.; James, C.D.; Collins, V.P. Identical splicing of aberrant epidermal growth factor receptor transcripts from amplified rearranged genes in human glioblastomas. Proc. Natl. Acad. Sci. USA 1990, 87, 8602-8606. [CrossRef] [PubMed]

67. Eskilsson, E.; Rosland, G.V.; Talasila, K.M.; Knappskog, S.; Keunen, O.; Sottoriva, A.; Foerster, S.; Solecki, G.; Taxt, T.; Jirik, R.; et al. EGFRvIII mutations can emerge as late and heterogenous events in glioblastoma development and promote angiogenesis through Src activation. Neuro Oncol. 2016, 18, 1644-1655. [CrossRef]

68. Crespo, I.; Vital, A.L.; Nieto, A.B.; Rebelo, O.; Tão, H.; Lopes, M.C.; Oliveira, C.R.; French, P.J.; Orfao, A.; Tabernero, M.D. Detailed Characterization of Alterations of Chromosomes 7, 9, and 10 in Glioblastomas as Assessed by Single-Nucleotide Polymorphism Arrays. J. Mol. Diagn. 2011, 13, 634-647. [CrossRef]

69. Kanwal, R.; Gupta, S. Epigenetic modifications in cancer. Clin. Genet. 2012, 81, 303-311. [CrossRef]

70. Delpu, Y.; Cordelier, P.; Cho, W.C.; Torrisani, J. DNA methylation and cancer diagnosis. Int. J. Mol. Sci. 2013, 14, 15029-15058. [CrossRef]

71. Malmstrom, A.; Gronberg, B.H.; Marosi, C.; Stupp, R.; Frappaz, D.; Schultz, H.; Abacioglu, U.; Tavelin, B.; Lhermitte, B.; Hegi, M.E.; et al. Temozolomide versus standard 6-week radiotherapy versus hypofractionated radiotherapy in patients older than 60 years with glioblastoma: The Nordic randomised, phase 3 trial. Lancet Oncol. 2012, 13, 916-926. [CrossRef]

72. Perry, J.R.; Laperriere, N.; O'Callaghan, C.J.; Brandes, A.A.; Menten, J.; Phillips, C.; Fay, M.; Nishikawa, R.; Cairncross, J.G.; Roa, W.; et al. Short-course radiation plus temozolomide in elderly patients with glioblastoma. N. Engl. J. Med. 2017, 376, 1027-1037. [CrossRef] [PubMed]

73. Christmann, M.; Kaina, B. Epigenetic regulation of DNA repair genes and implications for tumor therapy. Mutat. Res. 2019, 780, 15-28. [CrossRef] [PubMed]

74. Bouras, E.; Karakioulaki, M.; Bougioukas, K.I.; Aivaliotis, M.; Tzimagiorgis, G.; Chourdakis, M. Gene promoter methylation and cancer: An umbrella review. Gene 2019, 710, 333-340. [CrossRef] [PubMed]

75. Donson, A.M.; Addo-Yobo, S.O.; Handler, M.H.; Gore, L.; Foreman, N.K. MGMT promoter methylation correlates with survival benefit and sensitivity to temozolomide inpediatric glioblastoma. Pediatr. Blood Cancer 2007, 48, 403-407. [CrossRef]

76. Herrlinger, U.; Schafer, N.; Steinbach, J.P.; Weyerbrock, A.; Hau, P.; Goldbrunner, R.; Friedrich, F.; Rohde, V.; Ringel, F.; Schlegel, U.; et al. Bevacizumab plus irinotecan versus temozolomide in newly diagnosed O6-methylguanine-DNA methyltransferase nonmethylated glioblastoma: The randomized GLARIUS trial. J. Clin. Oncol. 2016, 34, 1611-1619. [CrossRef]

77. Minniti, G.; Scaringi, C.; Arcella, A.; Lanzetta, G.; Di Stefano, D.; Scarpino, S.; Bozzao, A.; Pace, A.; Villani, V.; Salvati, M.; et al. IDH1 mutation and MGMT methylation status predict survival in patients with anaplastic astrocytoma treated with temozolomide-based chemoradiotherapy. J. Neurooncol. 2014, 118, 377-383. [CrossRef]

78. Baumert, B.G.; Hegi, M.E.; van den Bent, M.J.; von Deimling, A.; Gorlia, T.; Hoang-Xuan, K.; Brandes, A.A.; Kantor, G.; Taphoorn, M.J.B.; Hassel, M.B.; et al. Temozolomide chemotherapy versus radiotherapy in 
high-risk lowgrade glioma (EORTC 22033-26033): A randomised, open-label, phase 3 intergroup study. Lancet Oncol. 2016, 17, 1521-1532. [CrossRef]

79. Bady, P.; Delorenzi, M.; Hegi, M.E. Sensitivity analysis of the MGMT-STP27 model and impact of genetic and epigenetic context to predict the MGMT methylation status in gliomas and other tumors. J. Mol. Diagn. 2016, 18, 350-361. [CrossRef]

80. Vlassenbroeck, I.; Califice, S.; Diserens, A.C.; Migliavacca, E.; Straub, J.; Di Stefano, I.; Moreau, F.; Hamou, M.F.; Renard, I.; Delorenzi, M.; et al. Validation of real-time methylation-specific PCR to determine O6-methylguanine-DNA methyltransferase gene promoter methylation in glioma. J. Mol.Diagn. 2008, 10, 332-337. [CrossRef]

81. Bady, P.; Diserens, A.C.; Castella, V.; Kalt, S.; Heinimann, K.; Hamou, M.F.; Delorenzi, M.; Hegi, M.E. DNA fingerprinting of glioma cell lines and considerations on similarity measurements. Neuro Oncol. 2012, 14, 701-711. [CrossRef]

82. Van den Bent, J.; Erdem Eraslan, L.; Idbaih, A.; de Rooi, J.J.; Eilers, P.H.; Spliet, W.; den Dunnen, W.F.; Tijssen, C.; Wesseling, P.; Sillevis Smitt, P.A.; et al. MGMT-STP27 methylation status as predictive marker for response to PCVin anaplastic oligodendrogliomas and oligoastrocytomas. A report from EORTCstudy 26951. Clin. Cancer Res. 2013, 19, 5513-5522. [CrossRef] [PubMed]

83. Loeb, L.A. Mutator phenotype may be required for multistage carcinogenesis. Cancer Res. 1991, 51, $3075-3079$. [PubMed]

84. Bielas, J.H.; Loeb, K.R.; Rubin, B.P.; True, L.D.; Loeb, L.A. Human cancers express a mutator phenotype. Proc. Natl. Acad. Sci. USA 2006, 103, 18238-18242. [CrossRef] [PubMed]

85. Holland, A.J.; Cleveland, D.W. Boveri revisited: Chromosomal instability, aneuploidy and tumorigenesis. Nat. Rev. Mol. Cell Biol. 2009, 10, 478-487. [CrossRef] [PubMed]

86. Orr, B.; Godek, K.M.; Compton, D. Aneuploidy. Curr Biol. 2015, 25, R538-R542. [CrossRef] [PubMed]

87. Lee, A.; Endesfelder, D.; Rowan, A.J.; Walther, A.; Birkbak, N.J.; Futreal, A.P.; Downward, J.; Szallasi, Z.; Tomlinson, I.P.; Howell, M.; et al. Chromosomal instability confers intrinsic multidrug resistance. Cancer Res. 2011, 71, 1858-1870. [CrossRef] [PubMed]

88. Woehrer, A.; Sander, P.; Haberler, C.; Kern, S.; Maier, H.; Preusser, M.; Hartmann, C.; Kros, J.M.; Hainfellner, J.A. FISH-based detection of $1 \mathrm{p} 19 \mathrm{q}$ codeletion in oligodendroglial tumors: Procedures and protocols for neuropathological practice-A publication under the auspices of the Research Committee of the European Confederation of Neuropathological Societies (Euro-CNS). Clin. Neuropathol. 2011, 30, 47-55. [CrossRef]

89. Griffin, C.A.; Burger, P.; Morsberger, L.; Yonescu, R.; Swierczynski, S.; Weingart, J.D.; Murphy, K.M. Identification of der(1;19)(q10;p10) in five oligodendrogliomas suggests mechanism of concurrent $1 \mathrm{p}$ and 19q loss. J. Neuropathol. Exp. Neurol. 2006, 65, 988-994. [CrossRef]

90. Jenkins, R.B.; Blair, H.; Ballman, K.V.; Giannini, C.; Arusell, R.M.; Law, M.; Flynn, H.; Passe, S.; Felten, S.; Brown, P.D.; et al. A t(1;19)(q10;p10) mediates the combined deletions of $1 \mathrm{p}$ and $19 \mathrm{q}$ and predicts a better prognosis of patients with oligodendroglioma. Cancer Res. 2006, 66, 9852-9861. [CrossRef]

91. Ostrom, Q.T.; Bauchet, L.; Davis, F.G.; Deltour, I.; Fisher, J.L.; Langer, C.E.; Pekmezci, M.; Schwartzbaum, J.A.; Turner, M.C.; Walsh, K.M.; et al. The epidemiology of glioma in adults: A "state of the science" review. Neuro Oncol. 2014, 16, 896-913. [CrossRef]

92. Idbaih, A.; Marie, Y.; Pierron, G.; Brennetot, C.; Hoang-Xuan, K.; Kujas, M.; Mokhtari, K.; Sanson, M.; Lejeune, J.; Aurias, A.; et al. Two types of chromosome 1p losses with opposite significance in gliomas. Ann. Neurol. 2005, 58, 483-487. [CrossRef] [PubMed]

93. Qu, M.; Olofsson, T.; Sigurdardottir, S.; You, C.; Kalimo, H.; Nistér, M.; Smits, A.; Ren, Z.P. Genetically distinct astrocytic and oligodendroglial components in oligoastrocytomas. Acta Neuropathol. 2007, 113, 129-136. [CrossRef] [PubMed]

94. Sim, J.; Nam, D.H.; Kim, Y.; Lee, I.H.; Choi, J.W.; Sa, J.K.; Suh, Y.L. Comparison of 1p and 19q status of glioblastoma by whole exome sequencing, array-comparative genomic hybridization, and fluorescence in situ hybridization. Med Oncol. 2018, 35, 60. [CrossRef] [PubMed]

95. Labussiere, M.; Idbaih, A.; Wang, X.W.; Marie, Y.; Boisselier, B.; Falet, C.; Paris, S.; Laffaire, J.; Carpentier, C.; Crinière, E.; et al. All the 1p19q codeleted gliomas are mutated on IDH1 or IDH2. Neurology 2010, 74, 1886-1890. [CrossRef] [PubMed] 
96. Yip, S.; Butterfield, Y.S.; Morozova, O.; Chittaranjan, S.; Blough, M.D.; An, J.; Birol, I.; Chesnelong, C.; Chiu, R.; Chuah, E.; et al. Concurrent CIC mutations, IDH mutations, and 1p/19q loss distinguish oligodendrogliomas from other cancers. J. Pathol. 2012, 226, 7-16. [CrossRef] [PubMed]

97. Bettegowda, C.; Agrawal, N.; Jiao, Y.; Sausen, M.; Wood, L.D.; Hruban, R.H.; Rodriguez, F.J.; Cahill, D.P.; McLendon, R.; Riggins, G.; et al. Mutations in CIC and FUBP1 contribute to human oligodendroglioma. Science 2011, 333, 1453-1455. [CrossRef] [PubMed]

98. Schaaf, C.P.; Wiszniewska, J.; Beaudet, A.L. Copy number and SNP arrays in clinical diagnostics. Annu. Rev. Genomics Hum. Genet. 2011, 12, 25-51. [CrossRef]

99. Synhaeve, N.E.; van den Bent, M.J.; French, P.J.; Dinjens, W.N.M.; Atmodimedjo, P.N.; Kros, J.M.; Verdijk, R.; Dirven, C.M.F.; Dubbink, H.J. Clinical evaluation of a dedicated next generation sequencing panel for routine glioma diagnostics. Acta Neuropathol. Commun. 2018, 6, 126. [CrossRef]

100. Nikiforova, M.N.; Wald, A.I.; Roy, S.; Durso, M.B.; Nikiforov, Y.E. Targeted next-generation sequenc ing panel (ThyroSeq) for detection of mutations in thyroid cancer. J. Clin. Endocrinol. Metab. 2013, 98, E1852-E1860. [CrossRef]

101. Wang, K.; Li, M.; Hakonarson, H. ANNOVAR: Functional annotation of genetic variants from high-throughput sequencing data. Nucleic Acids Res. 2010, 38, e164. [CrossRef]

102. Sherry, S.T.; Ward, M.H.; Kholodov, M.; Baker, J.; Phan, L.; Smigielski, E.M.; Sirotkin, K. dbSNP: The NCBI databas of genetic variation. Nucleic Acids Res. 2001, 29, 308-311. [CrossRef] [PubMed]

103. Ballester, L.Y.; Fuller, G.N.; Powell, S.Z.; Sulman, E.P.; Patel, K.P.; Luthra, R.; Routbort, M.J. Retrospective analysis of molecular and Immunohistochemical characterization of 381 primary brain tumors. J. Neuropathol. Exp. Neurol. 2017, 76, 179-188. [CrossRef]

104. Zacher, A.; Kaulich, K.; Stepanow, S.; Wolter, M.; Köhrer, K.; Felsberg, J.; Malzkorn, B.; Reifenberger, G. Molecular Diagnostics of Gliomas Using Next Generation Sequencing of a Glioma-Tailored Gene Panel. Brain Pathol. 2017, 27, 146-159. [CrossRef] [PubMed]

105. Chan, J.A.; Zhang, H.; Roberts, P.S.; Jozwiak, S.; Wieslawa, G.; Lewin-Kowalik, J.; Kotulska, K.; Kwiatkowski, D.J. Pathogenesis of tuberous sclerosis-subependymal giant cell astrocytomas: Biallelic inactivation of TSC1 or TSC2 leads to mTOR activation. J. Neuropathol. Exp. Neurol. 2004, 63, 1236-1242. [CrossRef] [PubMed]

106. Buczkowicz, P.; Hoeman, C.; Rakopoulos, P.; Pajovic, S.; Letourneau, L.; Dzamba, M.; Morrison, A.; Lewis, P.; Bouffet, E.; Bartels, U.; et al. Genomic analysis of diffuse intrinsic pontine gliomas identifies three molecular subgroups and recurrent activating ACVR1 mutations. Nat. Genet. 2014, 46, 451-456. [CrossRef] [PubMed]

107. Wu, G.; Broniscer, A.; McEachron, T.A.; Lu, C.; Paugh, B.S.; Becksfort, J.; Qu, C.; Ding, L.; Huether, R.; Parker, M.; et al. Somatic histone $\mathrm{H} 3$ alterations in pediatric diffuse intrinsic pontine gliomas and non-brainstem glioblastomas. Nat. Genet. 2012, 44, 251-253. [PubMed]

108. Virk, S.M.; Gibson, R.M.; Quinones-Mateu, M.E.; Barnholtz-Sloan, J.S. Identification of variants in primary and recurrent glioblastoma using a cancer-specific gene panel and whole exome sequencing. PLoS ONE 2015, 10, e0124178. [CrossRef]

109. Crowley, E.; Di Nicolantonio, F.; Loupakis, F.; Bardelli, A. Liquid biopsy: Monitoring cancer-genetics in the blood. Nat. Rev. Clin. Oncol. 2013, 10, 472-484. [CrossRef]

110. Skog, J.; Würdinger, T.; van Rijn, S.; Meijer, D.H.; Gainche, L.; Sena- Esteves, M.; Curry, W.T.; Carter, B.S.; Krichevsky, A.M.; Breakefield, X.O. Glioblastoma microvesicles transport RNA and proteins that promote tumour growth and provide diagnostic bio- markers. Nat. Cell. Biol. 2008, 10, 1470-1476. [CrossRef]

111. Ulz, P.; Thallinger, G.G.; Auer, M.; Graf, R.; Kashofer, K.; Jahn, S.W.; Abete, L.; Pristauz, G.; Petru, E.; Geigl, J.B.; et al. Inferring expressed genes by whole-genome sequencing of plasma DNA. Nat. Genet. 2016, 48, 1273-1278. [CrossRef]

112. El Messaoudi, S.; Rolet, F.; Mouliere, F.; Thierry, A.R. Circulating cell free DNA: Preanalytical considerations. Clin. Chim. Acta 2013, 424, 222-230. [CrossRef] [PubMed]

113. Jung, M.; Klotzek, S.; Lewandowski, M.; Fleischhacker, M.; Jung, K. Changes in concentration of DNA in serum and plasma during storage of blood samples. Clin. Chem. 2003, 49, 1028-1029. [CrossRef] [PubMed]

114. Bettegowda, C.; Sausen, M.; Leary, R.J.; Kinde, I.; Wang, Y.; Agrawal, N.; Bartlett, B.R.; Wang, H.; Luber, B.; Alani, R.M.; et al. Detection of circulating tumor DNA in early- and late-stage human malignancies. Sci. Transl. Med. 2014, 6, 224ra24. [CrossRef] [PubMed] 
115. Forshew, T.; Murtaza, M.; Parkinson, C.; Gale, D.; Tsui, D.W.Y.; Kaper, F.; Dawson, S.J.; Piskorz, A.M.; Jimenez-Linan, M.; Bentley, D.; et al. Noninvasive identification and monitoring of cancer mutations by targeted deep sequencing of plasma DNA. Sci. Transl. Med. 2012, 4, 136ra68. [CrossRef]

116. Merker, J.D.; Oxnard, G.R.; Compton, C.; Diehn, M.; Hurley, P.; Lazar, A.J.; Lindeman, N.; Lockwood, C.M.; Rai, A.J.; Schilsky, R.L.; et al. Circulating tumor DNA analysis in patients with cancer: American Society of Clinical Oncology and College of American Pathologists joint review. J. Clin. Oncol. 2014, 36, 1631-1641. [CrossRef] [PubMed]

117. De Mattos-Arruda, L.; Mayor, R.; Ng, C.K.; Weigelt, B.; Martinez-Ricarte, F.; Torrejon, D.; Oliveira, M.; Arias, A.; Raventos, C.; Tang, J.; et al. Cerebrospinal fluid-derived circulating tumour DNA better represents the genomic alterations of brain tumours than plasma. Nat. Commun. 2015, 6, 8839. [CrossRef]

118. Wang, Y.; Springer, S.; Zhang, M.; McMahon, K.W.; Kinde, I.; Dobbyn, L.; Ptak, J.; Brem, H.; Chaichana, K.; Gallia, G.L.; et al. Detection of tumor-derived DNA in cerebrospinal fluid of patients with primary tumors of the brain and spinal cord. Proc. Natl. Acad. Sci. USA 2015, 112, 9704-9709. [CrossRef]

119. Miller, A.M.; Shah, R.H.; Pentsova, E.I.; Pourmaleki, M.; Briggs, S.; Distefano, N.; Zheng, Y.; Skakodub, A.; Mehta, S.A.; Campos, C.; et al. Tracking tumour evolution in glioma through liquid biopsies of cerebrospinal fluid. Nature 2019, 565, 654-658. [CrossRef]

120. Chen, W.W.; Balaj, L.; Liau, L.M.; Samuels, M.L.; Kotsopoulos, S.K.; Maguire, C.A.; Loguidice, L.; Soto, H.; Garrett, M.; Zhu, L.D.; et al. BEAMing and Droplet Digital PCR Analysis of Mutant IDH1 mRNA in Glioma Patient Serum and Cerebrospinal Fluid Extracellular Vesicles. Mol. Ther. Nucleic Acids 2013, 2, e109. [CrossRef]

121. Liu, B.L.; Cheng, J.X.; Zhang, W.; Zhang, X.; Wang, R.; Lin, H.; Huo, J.L.; Cheng, H. Quantitative detection of multiple gene promoter hypermethylation in tumor tissue, serum, and cerebrospinal fluid predicts prognosis of malignant gliomas. Neuro Oncol. 2010, 12, 540-548. [CrossRef]

122. Drusco, A.; Bottoni, A.; Lagana, A.; Acunzo, M.; Fassan, M.; Cascione, L.; Antenucci, A.; Kumchala, P.; Vicentini, C.; Gardiman, M.P.; et al. A differentially expressed set of microRNAs in cerebro-spinal fluid (CSF) can diagnose CNS malignancies. Oncotarget 2015, 6, 20829-20839. [CrossRef] [PubMed]

123. Kopkova, A.; Sana, J.; Fadrus, P.; Slaby, O. Cerebrospinal fluid microRNAs as diagnostic biomarkers in brain tumors. Clin. Chem. Lab. Med. 2018, 56, 869-879. [CrossRef] [PubMed]

124. Murtaza, M.; Dawson, S.J.; Tsui, D.W.Y.; Gale, D.; Forshew, T.; Piskorz, A.M.; Parkinson, C.; Chin, S.F.; Kingsbury, Z.; Wong, A.S.; et al. Non-invasive analysis of acquired resistance to cancer therapy by sequencing of plasma DNA. Nature 2013, 497, 108-112. [CrossRef] [PubMed]

125. Akers, J.C.; Hua, W.; Li, H.; Ramakrishnan, V.; Yang, Z.; Quan, K.; Zhu, W.; Li, J.; Figueroa, J.; Hirshman, B.R.; et al. A cerebrospinal fluid microRNA signature as biomarker for glioblastoma. Oncotarget 2017, 8, 68769-68779. [CrossRef] [PubMed]

126. Liu, F.; Huang, J.; Liu, X.; Cheng, Q.; Luo, C.; Liu, Z. CTLA-4 correlates with immune and clinical characteristics of glioma. Cancer Cell. Int. 2020, 20, 7. [CrossRef] [PubMed]

127. Subbiah, V.; Kurzrock, R. The Marriage Between Genomics and Immunotherapy: Mismatch Meets Its Match. Oncologist 2019, 24, 1-3. [CrossRef]

128. Deng, X.; Lin, D.; Chen, B.; Zhang, X.; Xu, X.; Yang, Z.; Shen, X.; Yang, L.; Lu, X.; Sheng, H.; et al. Development and Validation of an IDH1-Associated Immune Prognostic Signature for Diffuse Lower-Grade Glioma. Front. Oncol. 2019, 9, 1310. [CrossRef]

129. Hao, Z.; Guo, D. EGFR mutation: Novel prognostic factor associated with immune infiltration in lower-grade glioma; an exploratory study. BMC Cancer 2019, 19, 1184. [CrossRef]

130. Chen, R.Q.; Liu, F.; Qiu, X.Y.; Chen, X.Q. The Prognostic and Therapeutic Value of PD-L1 in Glioma. Front. Pharmacol. 2019, 9, 1503. [CrossRef]

(C) 2020 by the authors. Licensee MDPI, Basel, Switzerland. This article is an open access article distributed under the terms and conditions of the Creative Commons Attribution (CC BY) license (http://creativecommons.org/licenses/by/4.0/). 